\title{
Design of Small-scale Biogas Plant for Household Need
}

Suthajini Thiruketheeswaranathan ${ }^{1 *} \&$ Anojan Dharshayini ${ }^{2}$

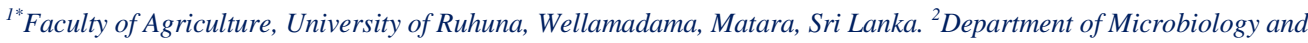
Biotechnology, Edinburgh Napier University, United Kingdom. DOI: 10.46431/MEJAST.2021.4305 permits unrestricted use, distribution, and reproduction in any medium, provided the original author and source are credited.

\section{ABSTRACT}

Bioenergy production is a promising way to manage the organic waste material while generating the heat and electricity. Anaerobic digestion of the organic material is gaining attraction due to its easy operation and the cost effectiveness. Biogas plant is an efficient bio energy production which mainly practices in developing country to transform waste into gas through the anaerobic digestion. It is a renewable energy source which helps to fulfil the energy need especially for developing country. In this research, the small-scale biogas plant was designed and implemented for household need with cow dung as a substrate. Biogas composition was measured with a multifunctional portable gas analyser. The mean content of methane $\left(\mathrm{CH}_{4}\right)$ was $63.64 \%$ and carbon dioxide $\left(\mathrm{CO}_{2}\right)$ was $29.04 \%$. Substrate was allowed for store in varying time, i.e., one week, two weeks, and three weeks before the digestion process to increase the bacterial community. The longer the manure/cow dung is stored in a closed container before pass through the digester, the shorter the time for the anaerobic decomposition process.

Keywords: Biogas, Domestic waste, Sustainability, Anaerobic digestion.

\section{Introduction}

The globe is facing number of environmental problems connected to anthropogenic activities. Global warming is probably the best known, and greenhouse gases such as carbon dioxide $\left(\mathrm{CO}_{2}\right)$, methane $\left(\mathrm{CH}_{4}\right)$ and nitrous oxide $\left(\mathrm{N}_{2} \mathrm{O}\right)$ are the main reason for it. Therefore, the reduction of greenhouse gases will entertain the reduction of global warming (Hoegh-Guldberg et al., 2017). Likewise, the environmental threats, energy crisis also the unbearable challenge of developing countries. Therefore the world lies in the available supply of affordable and sustainable eco-friendly renewable energy (Roubík et al., 2018). Biogas is a type of biofuel that is naturally produced from the decomposition of organic waste. The main purpose of producing biogas through anaerobic digestion of organic material is often to produce a renewable energy carrier that can replace fossil fuels. Biogas can contribute to fulfilling the target of European Union to reduce the GHG emission by $40 \%$ relative to 1990 levels (European Commission, 2014). When organic matter, such as food scraps and animal waste, break down in an anaerobic environment (an environment absents of oxygen) they release a blend of gases, primarily methane and carbon dioxide. Anaerobic digestion is also a sustainable waste management option for organic waste, in contrast to landfilling. Biogas is known as an environmentally friendly energy source because it alleviates two major environmental problems simultaneously: One is the global waste epidemic that releases dangerous levels of methane gas every day and other one is that the reliance on fossil fuel energy to meet global energy demand. According to the Renewable energy directive (European Parliament, 2018b) biogas production can contribute to a sustainable development.

Production of biogas through anaerobic digestion (AD) of animal manure and slurries as well as of a wide range of digestible organic wastes such as kitchen waste converts these substrates into renewable energy and offers a natural fertilizer for agriculture. At the same time, it removes the organic fraction from the overall waste streams, increasing this way the efficiency of energy conversion by incineration of the remaining wastes and the biochemical stability of landfill sites. 
Biogas mainly consists of methane $\left(\mathrm{CH}_{4}\right)(50-75 \%)$ and carbon dioxide $\left(\mathrm{CO}_{2}\right)(25-50 \%)$ water $\left(\mathrm{H}_{2} \mathrm{O}\right)$, oxygen $\left(\mathrm{O}_{2}\right)$, sulphur $\left(\mathrm{S}_{2}\right)$ and hydrogen sulphide $\left(\mathrm{H}_{2} \mathrm{~S}\right)$ (Wellinger et al., 2013). Börjesson and Mattiasson (2008) studied the resource efficiency of biogas as a vehicle fuel and conclude that biogas has the potential to become one of the most sustainable vehicle fuels.

Hydrolysis, acidogenesis, acetogenesis and methanogenesis are the four main steps of the digestion (Sarker et al., 2019). Different organic materials can be used as substrate (inputs) for the biogas production process including kitchen waste, industrial waste, agricultural waste slaughterhouse waste, sludge from wastewater treatment plants, manure and etc (Wellinger et al., 2013). Some range of Pre-treatment is needed based on the substrate type for example crushing or grinding and diluting.

$\mathrm{AD}$ is a microbiological process of decomposition of organic matter, in the absence of oxygen, common to many natural environments and largely applied today to produce biogas in airproof reactor tanks, commonly named digesters. A wide range of micro-organisms are involved in the anaerobic process which has two main end products: biogas and digestate. Biogas is a combustible gas consisting of methane, carbon dioxide and small amounts of other gases and trace elements. Digestate is the decomposed substrate, rich in macro- and micronutrients and therefore suitable to be used as plant fertilizer. AD not only reduce the organic waste, but also reduce the greenhouse gas emissions as well as water, soil and air pollution compared to landfilling (European Parliament, 2018a). It can be performed at different temperatures, most commonly at mesophilic $\left(35-40^{\circ} \mathrm{C}\right)$ or thermophilic $\left(55-60^{\circ} \mathrm{C}\right)$ temperatures.

Upgraded biogas is usually referred to as biomethane, same properties as natural gas (Scarlat et al., 2018). The composition of the digestate is influenced by the substrate materials which are used and the anaerobic process parameters (Drosg et al., 2015). Digestate can be used as a fertilizer for the cultivation, and it improves the microbiology of the soil, and thereby increases respiration and organic carbon (Hagman and Eklund, 2016). The present study focuses to design and develop the small-scale biogas plant for household need.

\section{Materials and Methods}

Digester tank, Inlet for feeding the waste, Outlet for the digested slurry, Gas collection and storage system are the basic components of a biogas plant. Biogas formation process must take place in digester which is free of oxygen. The shape and size of the digester can vary, according to the needs and available materials to make the digester.

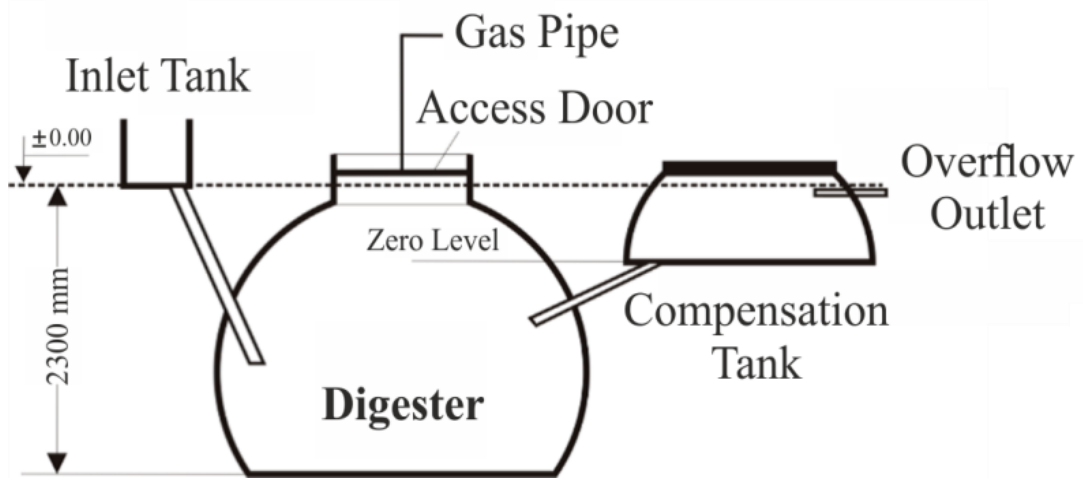

Fig.1. Structure of Biogas plant 
The digester is filled in through the inlet tank or inlet pipe. The produced biogas is accumulated at the upper part of the digester. In this experiment rubber tyre was used to accumulate the biogas. The slurry flows back into the digester from the compensation tank after the gas is released through the gas pipe to tyre. The above figure 1 shows the basic components and the structure of the biogas plant.

In this paper following materials were used to make this minimized biogas plant is a Water tank (1000 liters capacity) and some other equipment such as M-seal or any water-proof adhesive, gas collection tube/tyre and PVC Pipes and Valves. The material should be sufficiently elastic, to avoid the occurrence of cracks or leaks during the manufacturing process. Slurry derived from the wet cow dung was used as a substrate. Wet cow dung which we used in these experiments was stored in varying time, i.e., one week, two weeks, and three weeks. Days required to form a biogas was gathered based on the stored time of substrate.

\section{Results and Discussions}

The digester will come out through the gas outlet and then stored into the gas storage. This biogas plant was also equipped with manometer to measure the pressure inside the digester. The content of the biogas was analysed. The mean content of methane $\left(\mathrm{CH}_{4}\right)$ was $63.64 \%$ and carbon dioxide $\left(\mathrm{CO}_{2}\right)$ was $29.04 \%$. The following figure 2 shows the relationship between the storage time and the duration of biogas formation. The anaerobic decomposition is fast with the storing time due to the increment of bacteria community.

Erwin Randjawali, 2016 was concluded the same that the anaerobic decomposition is faster when the substrate is stored more. Therefore the longer the manure is stored in a closed container (before eventually mixed with water to be made into a slurry that will be incorporated into the digester), then the time it takes to do anaerobic decomposition process becomes shorter (Randjawali \& Waris, 2016). Only three weeks duration was allowed for the storage in a closed container. Therefore, we couldn't conclude whether the formation of biogas will be slower or faster when the substrate allows standing more time.

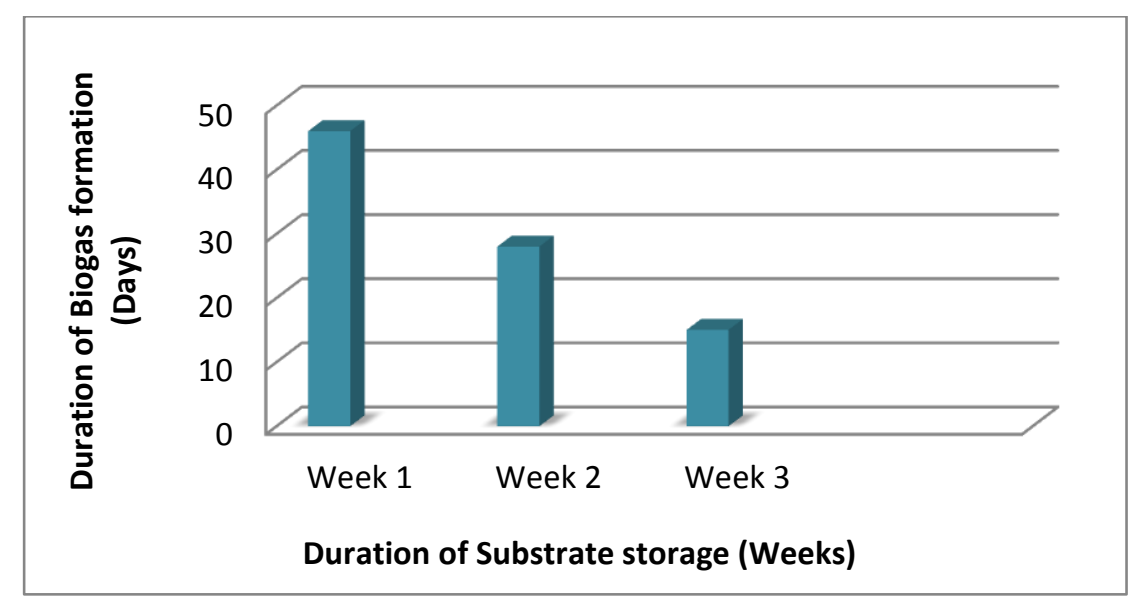

Fig.2. Number of days required to form biogas with pre storage of substrate

\section{Conclusion}

A small-scale biogas structure was designed implemented. It is useful for household energy need, the manure management and also helps to reduce the global warming impacts. 


\section{Declarations}

\section{Source of Funding}

This research did not receive any grant from funding agencies in the public, commercial, or not-for-profit sectors.

\section{Competing Interests Statement}

The authors declare no competing financial, professional and personal interests.

\section{Consent for publication}

Authors declare that they consented for the publication of this research work.

\section{Availability of data and material}

Authors are willing to share the data and material according to the relevant needs.

\section{References}

Börjesson, P. \& mattiasson, B. 2008. Biogas as a resource-efficient vehicle fuel. Trends in biotechnology, 26, 7-13. Drosg, B., Fuchs, W., AL Seadi, T., madsen, M. \& Linke, B. 2015. Nutrient recovery by biogas digestate processing. Dublin, Ireland: IEA Bioenergy.

European Commission 2014. A Policy Framework for Climate and Energy in the period from 2020 to 2030. Brussels, Belgium: European Commission.

European Parliament 2018. Council directive 86/278/EEC on the protection of the environment, and in particular of the soil, when sewage sludge is used in agriculture.

Hagman, L. \& Eklund, M. 2016. The role of biogas solutions in the circular and bio-based economy, Linköping, Sweden. Linköping University Electronic Press.

Hoegh-Guldberg,O., Poloczanska, E. S., Skirving, W. \& Dove, S. 2017. Coral reef ecosystems under climate change and ocean acidification. Frontiers in Marine Science, 4, 158.

Kinyua, M.N.; Rowse, L.E.; Ergas, S.J. Review of small-scale tubular anaerobic digesters treating livestock waste in the developing world. Renew. Sustain. Energy Rev. 2016, 58, 896-910.

Sarker, S., Lamb, J. J., Hjelme, D. R. \& Lien, K. M. 2019. A review of the role of critical parameters in the design and operation of biogas production plants. Applied Sciences, 9, 1915.

Randjawali, E., \& Waris, A. (2016). Design and testing of mini-size biogas plant. Journal of Physics: Conference Series, 739(1). https://doi.org/10.1088/1742-6596/739/1/012038.

Rasi, S. Biogas Composition and Upgrading to Biomethane; University of Jyväskylä: Jyväskylä, Finland, 2009; ISBN 978-951-39-3618-1.

Roubík, H., Mazancová, J., Le Dinh, P., Dinh Van, D., \& Banout, J. (2018). Biogas quality across small-scale biogas plants: A case of central Vietnam. Energies, 11(7), 1-12. https://doi.org/10.3390/en11071794.

Wellinger, A., Murphy, J. D. \& Baxter, D. 2013. The biogas handbook: science, production and applications, Cambridge, UK, Woodhead Publishing Limited. 